Article

\title{
Towards Highly Performing and Stable PtNi Catalysts in Polymer Electrolyte Fuel Cells for Automotive Application
}

\author{
Sabrina C. Zignani, Vincenzo Baglio *, David Sebastián, Ada Saccà, Irene Gatto and \\ Antonino S. Aricò
}

CNR-Istituto di Tecnologie Avanzate per l'Energia "Nicola Giordano", Via Salita S. Lucia sopra Contesse 5, 98126 Messina, Italy; zignani@itae.cnr.it (S.C.Z.); sebastian@itae.cnr.it (D.S.); sacca@itae.cnr.it (A.S.); gatto@itae.cnr.it (I.G.); arico@itae.cnr.it (A.S.A.)

* Correspondence: baglio@itae.cnr.it; Tel.: +39-90-624237

Academic Editor: Federico Bella

Received: 28 December 2016; Accepted: 15 March 2017; Published: 21 March 2017

\begin{abstract}
In order to help the introduction on the automotive market of polymer electrolyte fuel cells (PEFCs), it is mandatory to develop highly performing and stable catalysts. The main objective of this work is to investigate $\mathrm{PtNi} / \mathrm{C}$ catalysts in a PEFC under low relative humidity and pressure conditions, more representative of automotive applications. Carbon supported PtNi nanoparticles were prepared by reduction of metal precursors with formic acid and successive thermal and leaching treatments. The effect of the chemical composition, structure and surface characteristics of the synthesized samples on their electrochemical behavior was investigated. The catalyst characterized by a larger Pt content $\left(\mathrm{Pt}_{3} \mathrm{Ni}_{2} / \mathrm{C}\right)$ presented the highest catalytic activity (lower potential losses in the activation region) among the synthesized bimetallic PtNi catalysts and the commercial $\mathrm{Pt} / \mathrm{C}$, used as the reference material, after testing at high temperature $\left(95^{\circ} \mathrm{C}\right)$ and low humidification $(50 \%)$ conditions for automotive applications, showing a cell potential (ohmic drop-free) of $0.82 \mathrm{~V}$ at $500 \mathrm{~mA} \cdot \mathrm{cm}^{-2}$. In order to assess the electro-catalysts stability, accelerated degradation tests were carried out by cycling the cell potential between $0.6 \mathrm{~V}$ and $1.2 \mathrm{~V}$. By comparing the electrochemical and physico-chemical parameters at the beginning of life (BoL) and end of life (EoL), it was demonstrated that the $\mathrm{Pt}_{1} \mathrm{Ni}_{1} / \mathrm{C}$ catalyst was the most stable among the catalyst series, with only a $2 \%$ loss of voltage at $200 \mathrm{~mA} \cdot \mathrm{cm}^{-2}$ and $12.5 \%$ at $950 \mathrm{~mA} \cdot \mathrm{cm}^{-2}$. However, further improvements are needed to produce durable catalysts.
\end{abstract}

Keywords: PtNi/C catalyst; oxygen reduction reaction; polymer electrolyte fuel cell; accelerated degradation test

\section{Introduction}

Fuel cell technology is very close to the market application; however, a further optimization and a decrease of costs are still necessary [1,2]. Furthermore, for an easy thermal and water management, the automotive fuel cell market requires an increase of the operating temperature (in the range $90-130{ }^{\circ} \mathrm{C}$ ) and operation with a relative humidity (R.H.) less than $50 \%$ [3]. In order to increase the performance and reduce the $\mathrm{Pt}$ content in the electrodes, several approaches have been pursued, such as the use of binary and ternary Pt-alloys, e.g., $\mathrm{PtCo}, \mathrm{PtNi}, \mathrm{PtCoCr}, \mathrm{PtCoMn}[4-11]$, and, more recently, in order to decrease the cost, platinum group metal-free (PGM-free) catalysts [12-14].

Several works reported an enhancement of the oxygen reduction reaction (ORR) activity by factors of 1.5 to 3 for Pt-alloys in comparison to pure Pt, due to electronic and structural effects. One of the most promising and studied formulations is Pt-Ni [15-22], with mass activities exceeding those of 
carbon supported high surface area Pt and Pt-alloy catalysts [23]. Stamenkovic et al. [24] reported that the (111) surface of $\mathrm{Pt}_{3} \mathrm{Ni}$ exhibits a 10-fold higher ORR activity than $\mathrm{Pt}$ (111) and a 90-fold higher ORR activity than commercial $\mathrm{Pt} / \mathrm{C}$ catalysts. Although several mechanisms have been proposed to explain the high ORR activity of Pt-Ni structures [25,26], the best composition is still not clear, in particular under practical fuel cell conditions. Furthermore, these catalysts show insufficient durability, and suffer from a loss of structural integrity by metal segregation and de-alloying [16]. These limitations may be addressed by developing well-defined catalyst compositions and structures using proper preparation procedures. Some preparation procedures can effectively produce stable catalysts with an enrichment of $\mathrm{Pt}$ in the outermost layers of alloyed bimetallic catalysts $[7,27,28]$. These regard an induced surface segregation of Pt by high-temperature annealing and a removal of the less noble transition metal from the alloy surface by pre-leaching in an appropriate acid. This approach also produces better electrochemical activity, as reported in the literature $[7,27,28]$. Accordingly, in this work, we have prepared various $\mathrm{PtNi} / \mathrm{C}$ catalysts, characterized by different atomic compositions, by using the formic acid reduction method and successive annealing treatment at $900{ }^{\circ} \mathrm{C}$. We have used this preparation procedure because it is simpler, allowing the simultaneous reduction of $\mathrm{Pt}$ and $\mathrm{Ni}$ in a single step, and less time-consuming than other preparation procedures reported in the literature (i.e., sulphite-complex route) [3], in which the preparation of $\mathrm{PtNi} / \mathrm{C}$ catalyst generally comprises at least two processes concerning first $\mathrm{Pt} / \mathrm{C}$ synthesis and then $\mathrm{Ni}$ addition to $\mathrm{Pt}$ nanoparticles, with one or more thermal treatment and acid leaching steps. A leaching procedure in $0.5 \mathrm{M} \mathrm{HClO}_{4}$ was carried out for the synthesized PtNi catalysts after the thermal treatment to remove the non-alloyed $\mathrm{Ni}$ atoms from the surface. To shed a light on the better atomic composition of Pt-Ni electrocatalysts, the samples were electrochemically investigated in a polymer electrolyte fuel cell (PEFC) in terms of performance and stability to accelerated degradation tests. Despite the potential application of $\mathrm{PtNi} / \mathrm{C}$ catalysts in PEFC, few works in the literature report on the performance evaluation under realistic conditions $[8,29-31]$. The main objective of this work is thus to investigate PtNi/C catalysts in a PEFC under low relative humidity and pressure conditions, more representative of automotive applications.

\section{Results and Discussion}

\subsection{Physico-Chemical Characterization}

Figure 1 shows the $X$-ray diffraction (XRD) patterns of carbon supported $\mathrm{Pt}_{1} \mathrm{Ni}_{1} / \mathrm{KB}, \mathrm{Pt}_{3} \mathrm{Ni}_{2} / \mathrm{KB}$ and $\mathrm{Pt}_{2} \mathrm{Ni}_{3} / \mathrm{KB}$ as prepared, treated at $900{ }^{\circ} \mathrm{C}$ and leached after the thermal treatment. XRD patterns of the $\mathrm{Pt}_{1} \mathrm{Ni}_{1} / \mathrm{KB}$, reported in Figure 1a show a disordered cubic structure (fcc) for the as-prepared catalyst and a single ordered primitive cubic $\left(\mathrm{L1}_{2}\right)$ phase for the alloy treated at $900{ }^{\circ} \mathrm{C}$. The occurrence of the primitive cubic structure in the sample treated at high temperature is evident from the presence of the superlattice reflections, i.e., (001), (110) and (210) and from a better matching with the Joint Committee on Powder Diffraction Standards (JCPDS) card (65-2797) than the JCPDS card (04-0802) related to Pt. The as-prepared catalyst does not show any significant separation between $\mathrm{Ni}$ and Pt probably due to the low level of crystallinity, and after the high temperature treatment $\left(900{ }^{\circ} \mathrm{C}\right)$, no separation of metallic Ni phase was observed. A shift towards higher Bragg angles is observed, indicating the formation of the solid solution between $\mathrm{Pt}$ and $\mathrm{Ni}$, with a $35 \mathrm{at} \%$ of $\mathrm{Ni}$ in the alloy (Table 1). As reported in Table 1, the crystallite size after the thermal treatment is about $2.7 \mathrm{~nm}$.

The catalyst prepared with an excess of $\mathrm{Pt}\left(\mathrm{Pt}_{3} \mathrm{Ni}_{2} / \mathrm{KB}\right)$, whose XRD patterns are reported in Figure 1b, shows small crystallites, about $2.3 \mathrm{~nm}$, but also the presence of Ni hydroxide species for the as-prepared catalyst (see the shoulder at about $35^{\circ} 2 \theta$ ) that evolve with the formation of a separate metallic Ni phase at $900{ }^{\circ} \mathrm{C}$ (not clearly visible, since the Ni peaks are very close to Pt reflections). Thereafter, the effect of leaching was investigated. This post-treatment promoted the dissolution of unalloyed $\mathrm{Ni}$, as proven by the XRD analysis. Nonetheless, a suitable alloying (close to the bulk composition, see Table 1) was achieved as proven by the shift of fcc reflections. 
In the case of the catalyst containing an excess of $\mathrm{Ni}\left(\mathrm{Pt}_{2} \mathrm{Ni}_{3} / \mathrm{C}\right)$, whose XRD patterns are reported in Figure 1c, the presence of sharp peaks indicating large crystallites of metallic Ni after the thermal treatment (JCPDS card 1-1258) is evident. For the as-prepared catalyst, the presence of Ni hydroxides is clearly evident. After the thermal treatment at $900^{\circ} \mathrm{C}$, the formation of two separate metallic phases occurs, one rich in $\mathrm{Ni}$ and the other in $\mathrm{Pt}$. After the leaching post-treatment, only a slightly modification is achieved and the two separate phases are still present. However, a certain degree of alloying is obtained ( $26 \% \mathrm{Ni}$ in the alloy). The crystallite size for the Pt phase is larger than $6 \mathrm{~nm}$, as reported in Table 1.

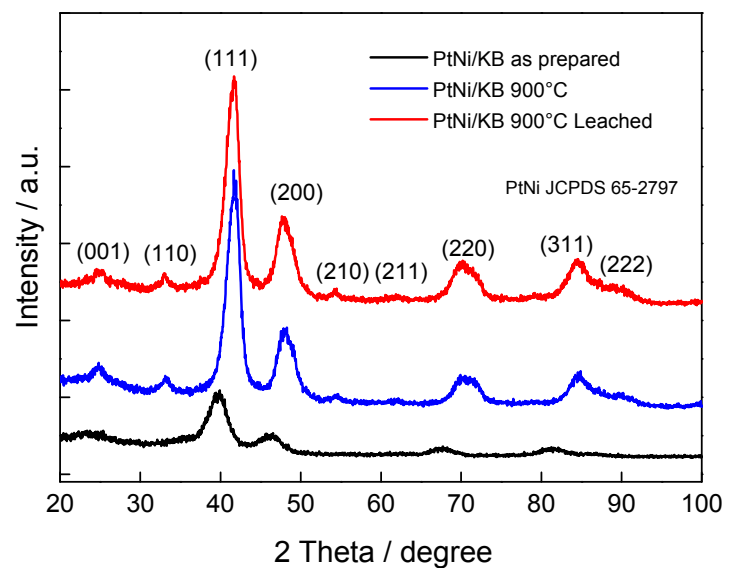

(a)

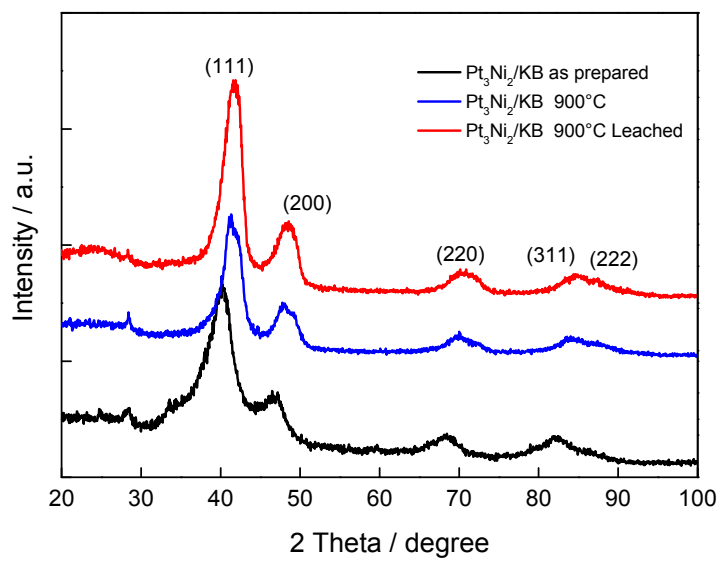

(b)

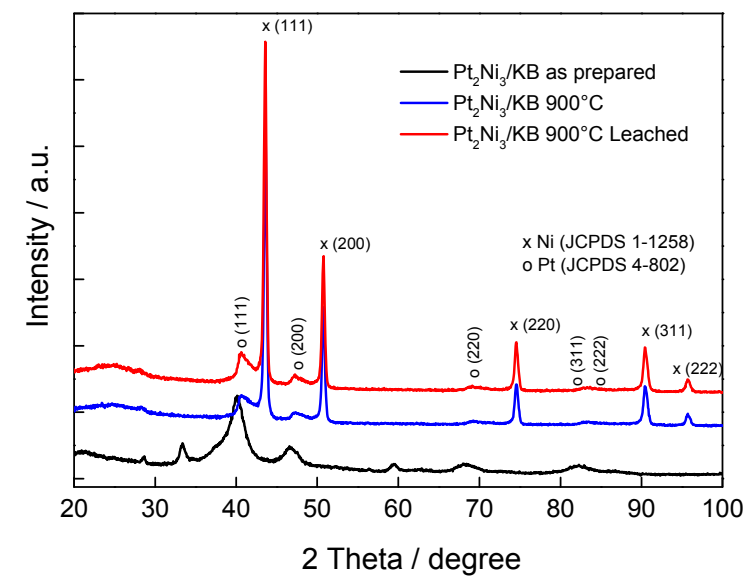

(c)

Figure 1. XRD patterns of carbon supported (a) $\mathrm{Pt}_{1} \mathrm{Ni}_{1}$; (b) $\mathrm{Pt}_{3} \mathrm{Ni}_{2}$; and (c) $\mathrm{Pt}_{2} \mathrm{Ni}_{3}$ catalysts (as-prepared, treated at $900{ }^{\circ} \mathrm{C}$ and leached).

Table 1. Physico-chemical properties of prepared catalysts.

\begin{tabular}{ccccc}
\hline Sample Catalyst & Position (200), ${ }^{\circ} \mathbf{2 0}$ & Crystallite Size, $\mathbf{n m}$ & Lattice Parameter (200), $\mathbf{n m}$ & $\boldsymbol{X}_{\mathbf{N i}}$ Alloy, $\%$ \\
\hline $\mathrm{PtNi} / \mathrm{KB}$ & 70.348 & 2.7 & 0.378 & 35 \\
$\mathrm{Pt}_{3} \mathrm{Ni}_{2} / \mathrm{KB}$ & 70.608 & 2.3 & 0.377 & 38 \\
$\mathrm{Pt}_{2} \mathrm{Ni}_{3} / \mathrm{KB}$ & 69.617 & 6.5 & 0.382 & 26 \\
\hline
\end{tabular}

A morphological analysis of the dispersion of the metallic particles on carbon (Figure 2) shows an increase of the particle size for the sample with a larger Ni content (average Pt particle size of $7.6 \mathrm{~nm}$ ). Particle sizes around $4.5 \mathrm{~nm}$ are observed for the $\mathrm{Pt}_{1} \mathrm{Ni}_{1}$ and $\mathrm{Pt}_{3} \mathrm{Ni}_{2}$ treated at $900{ }^{\circ} \mathrm{C}$. On the other hand, the commercial $\mathrm{Pt} / \mathrm{C}$ catalyst $(\mathrm{E}-\mathrm{TEK})$ exhibits a narrow particle size distribution with average size of $4.7 \mathrm{~nm}$. 

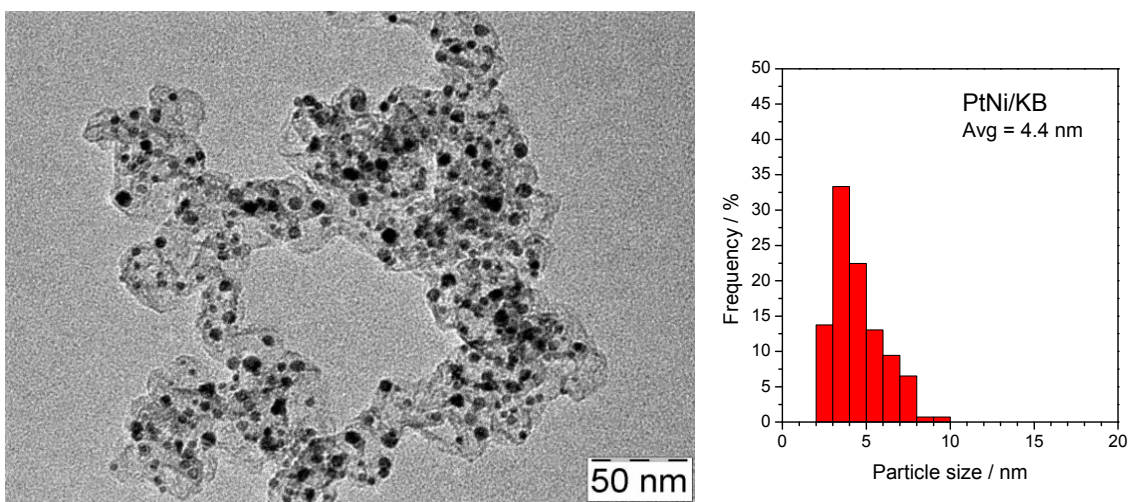

(a)
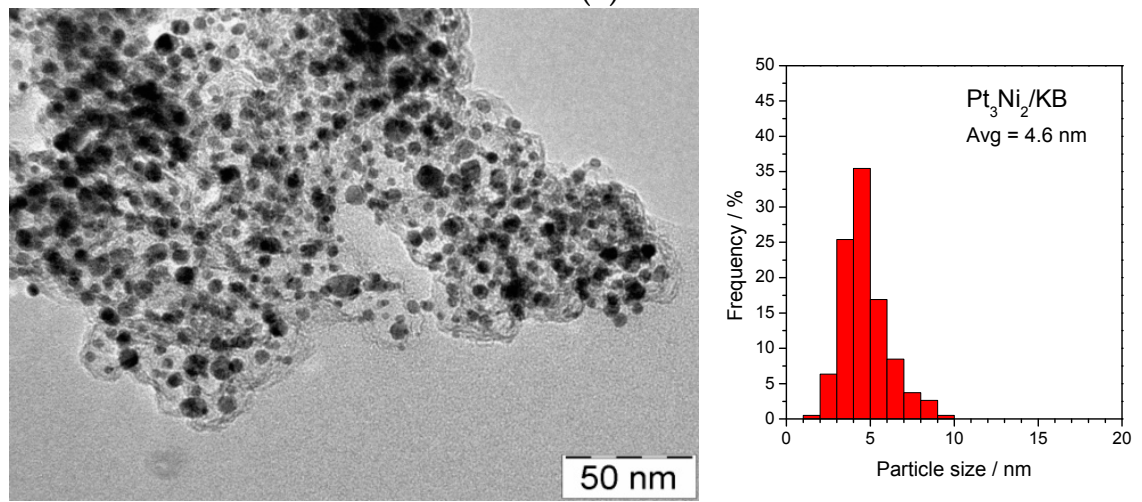

(b)
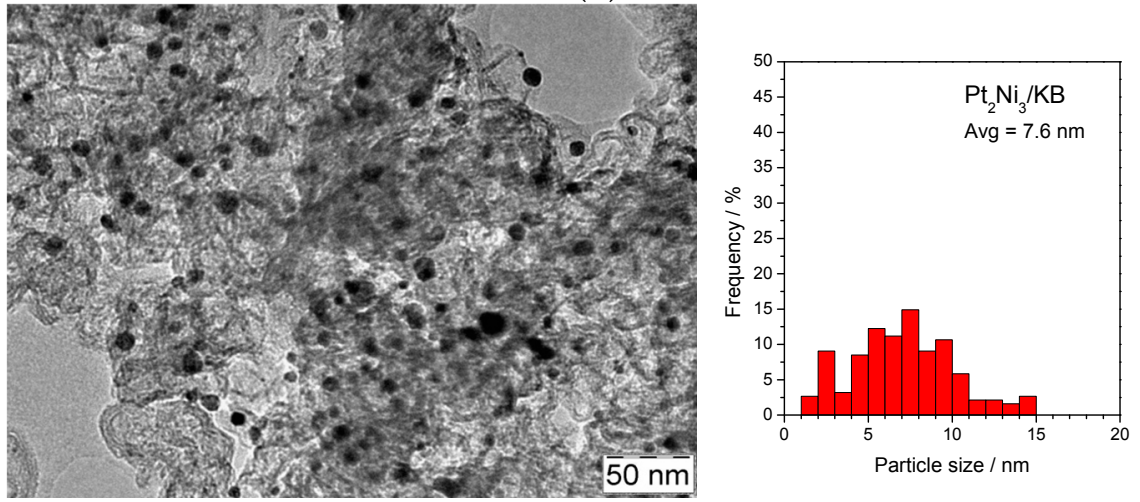

(c)
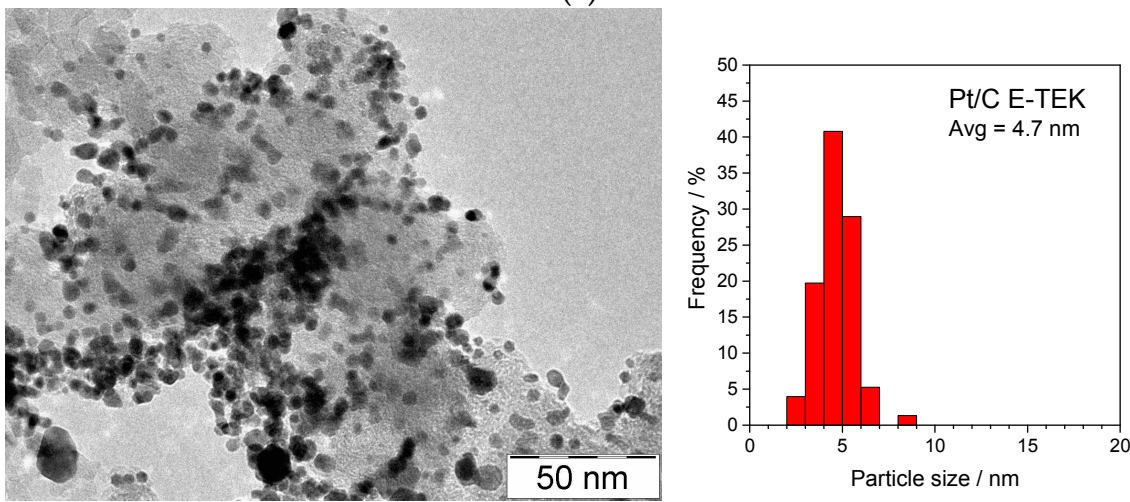

(d)

Figure 2. Transmission electron micrographs (TEM) analysis of carbon supported (a) $\mathrm{Pt}_{1} \mathrm{Ni}_{1} ;$ (b) $\mathrm{Pt}_{3} \mathrm{Ni}_{2}$; (c) $\mathrm{Pt}_{2} \mathrm{Ni}_{3}$ catalysts after the thermal and leaching treatments and (d) $\mathrm{Pt} / \mathrm{C}$ E-TEK catalyst. 
A surface characterization of the Pt-Ni samples was carried out by X-ray photoelectron spectroscopy (XPS). There was no significant change in the surface composition of the samples compared to the Pt:Ni ratio of their bulk compositions as evaluated by the energy dispersive $\mathrm{X}$-ray analysis (EDX) analysis (not shown). Figure 3a shows the $\mathrm{Pt} 4 \mathrm{f}$ and $\mathrm{Ni} 2 \mathrm{p}$ spectra of the $\mathrm{Pt}_{1} \mathrm{Ni}_{1} / \mathrm{C}$ sample as prepared. In the case of $\mathrm{Pt}$, the analysis of the photoelectron spectra indicates similar occurrence of metallic and oxidized $\mathrm{Pt}(2+)$ on the surface. Regarding Ni 2p, the deconvolution of the main bands shows a prevalence of hydroxide and oxide species; whereas, a very low amount of metallic Ni is present in the surface. The presence of such hydroxide and oxide species in the outermost layers may be due to the oxidation of surface Ni species.
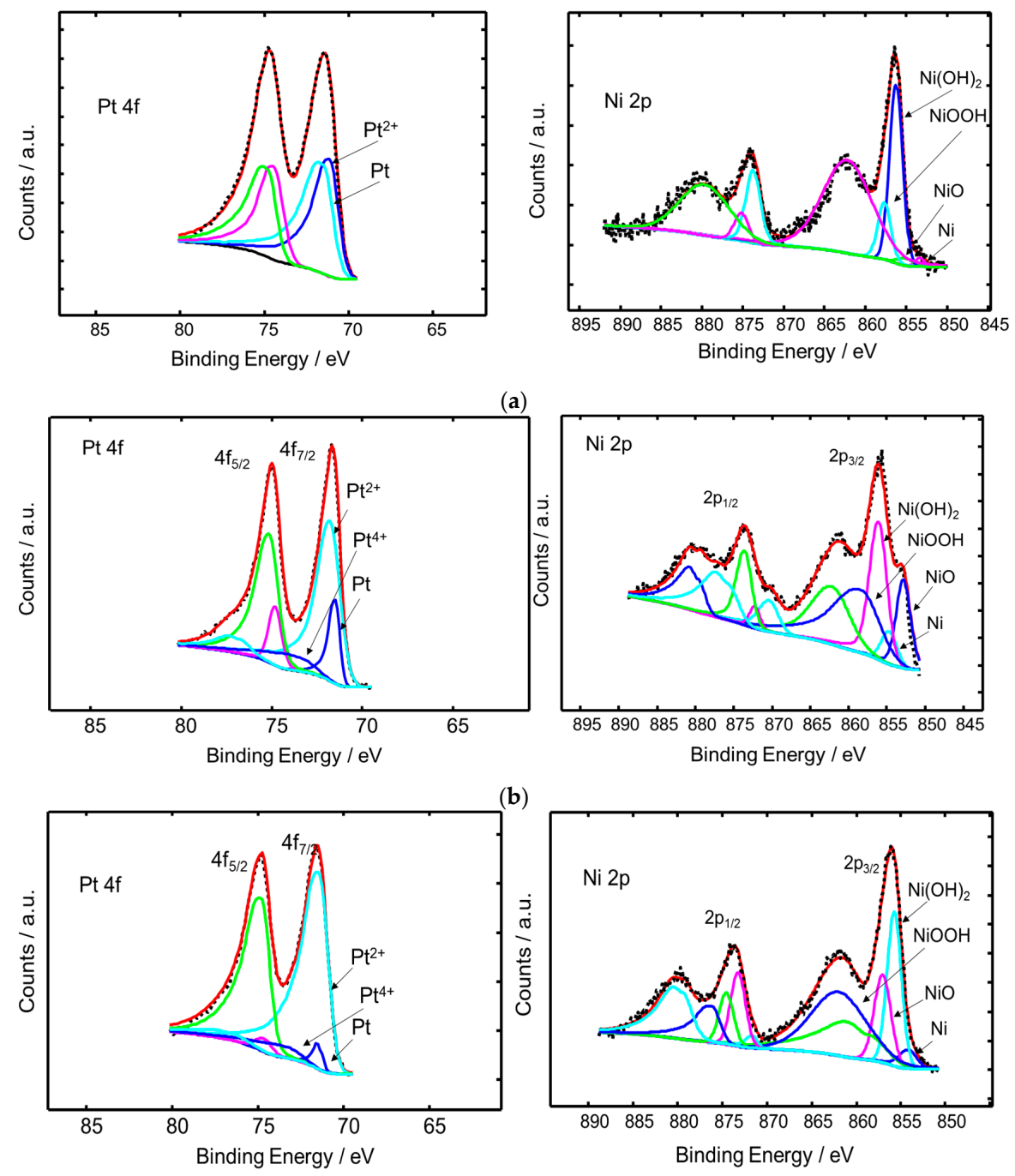

(c)

Figure 3. XPS spectra of $\mathrm{Pt} 4 \mathrm{f}$ and $\mathrm{Ni} 2 \mathrm{p}$ signals for carbon supported (a) $\mathrm{Pt}_{1} \mathrm{Ni}_{1} ;$ (b) $\mathrm{Pt}_{3} \mathrm{Ni}_{2}$; and $(c) \mathrm{Pt}_{2} \mathrm{Ni}_{3}$ catalysts after the thermal and leaching treatments.

The XPS analysis of the sample containing an excess of $\mathrm{Pt}\left(\mathrm{Pt}_{3} \mathrm{Ni}_{2} / \mathrm{C}\right)$ is reported in Figure $3 b$. Based on the quantitative determination reported in Table 2, it is possible to state that this sample shows a more oxidised $\mathrm{Pt}$ on the surface than the $\mathrm{Pt}_{1} \mathrm{Ni}_{1}$. Furthermore, this sample shows that $\mathrm{Ni}$ is, also in this case, largely present as hydroxide and oxide species on the surface with a small amount of zero-valent $\mathrm{Ni}$.

The XPS analysis of the sample containing an excess of $\mathrm{Ni}\left(\mathrm{Pt}_{2} \mathrm{Ni}_{3} / \mathrm{C}\right)$ shows that $\mathrm{Pt}$ is essentially occurring on the surface as $\mathrm{Pt}^{2+}$, whereas the Ni occurs as hydroxide and oxide species (Figure 3c). 
A complete dataset of the surface composition and surface oxidation states of the investigated samples is reported in Table 2 .

Table 2. Physico-chemical properties of prepared catalysts.

\begin{tabular}{|c|c|c|c|}
\hline Sample & Chemical States & Relative Peak Area (\%) & $\mathrm{BE}(\mathrm{eV})$ \\
\hline \multirow[t]{8}{*}{ PtNi/KB } & & & $4 f_{7 / 2}$ \\
\hline & Metallic Pt & 48.19 & 71.11 \\
\hline & $\mathrm{Pt}^{2+}$ & 51.81 & 71.49 \\
\hline & & & $2 p_{3 / 2}$ \\
\hline & Metallic Ni & 2.53 & 853.38 \\
\hline & $\mathrm{NiO}$ & 3.29 & 855.18 \\
\hline & $\mathrm{NiOOH}$ & 70.95 & 856.28 \\
\hline & $\mathrm{Ni}(\mathrm{OH})_{2}$ & 23.23 & 857.71 \\
\hline \multirow[t]{9}{*}{$\mathrm{Pt}_{3} \mathrm{Ni}_{2} / \mathrm{KB}$} & & & $4 f_{7 / 2}$ \\
\hline & Metallic Pt & 16.88 & 71.51 \\
\hline & $\mathrm{Pt}^{2+}$ & 70.88 & 71.80 \\
\hline & $\mathrm{Pt}^{4+}$ & 12.24 & 73.46 \\
\hline & & & $2 \mathrm{p}_{3 / 2}$ \\
\hline & Metallic Ni & 19.74 & 852.86 \\
\hline & $\mathrm{NiO}$ & 7.19 & 854.74 \\
\hline & $\mathrm{NiOOH}$ & 36.64 & 856.12 \\
\hline & $\mathrm{Ni}(\mathrm{OH})_{2}$ & 36.43 & 862.16 \\
\hline \multirow[t]{9}{*}{$\mathrm{Pt}_{2} \mathrm{Ni}_{3} / \mathrm{KB}$} & & & $4 f_{7 / 2}$ \\
\hline & Metallic Pt & 3.96 & 71.34 \\
\hline & $\mathrm{Pt}^{2+}$ & 88.38 & 71.43 \\
\hline & $\mathrm{Pt}^{4+}$ & 7.66 & 73.27 \\
\hline & & & $2 p_{3 / 2}$ \\
\hline & Metallic Ni & 5.67 & 854.18 \\
\hline & $\mathrm{NiO}$ & 34.84 & 855.75 \\
\hline & $\mathrm{NiOOH}$ & 23.35 & 857.06 \\
\hline & $\mathrm{Ni}(\mathrm{OH})_{2}$ & 36.14 & 858.71 \\
\hline
\end{tabular}

\subsection{Electrochemical Characterization}

The electrochemical performance of the $\mathrm{PtNi} / \mathrm{C}$ cathodic catalysts prepared by the formic acid method and successive thermal and leaching treatments was evaluated in a single cell based on a thin Nafion NR212 membrane. This was selected in order to increase the operating temperature of the PEFC device, reducing simultaneously the relative humidity (R.H.) and pressure to simulate the automotive conditions. However, initially, the cells were conditioned and investigated at $80^{\circ} \mathrm{C}$ and full humidification (100\% R.H., 3 bar $\left._{\mathrm{abs}}\right)$ as reference conditions. The polarization curves under the latter conditions and in the presence of air as the oxidant are reported in Figure 4a. They show a similar performance for $\mathrm{Pt}_{1} \mathrm{Ni}_{1} / \mathrm{C}, \mathrm{Pt}_{3} \mathrm{Ni}_{2} / \mathrm{C}$ and the benchmark $\mathrm{Pt} / \mathrm{C}$ catalyst, in particular, in the low current density (activation) region; whereas, at high current density, the cell equipped with the benchmark catalyst appears slightly better performing than the other catalysts. On the other hand, the behavior of the catalyst rich in $\mathrm{Ni}$ and with the presence of large metallic Ni particles was not showing a performance level than the other cathode catalysts investigated (Figure 4). This was due to the large particle size and the presence of two separate phases (PtNi and metallic Ni). The presence of the Ni phase can be also responsible of the high cell resistance recorded for the cell based on this catalyst, as can be observed in Table 3.

In order to exacerbate the differences among the curves, oxygen was fed at the cathode and the polarization curves (Figure $4 \mathrm{~b}$ ) were also recorded under these conditions $\left(80^{\circ} \mathrm{C}, 100 \%\right.$ R.H., 3 bar $\left._{a b s}\right)$. 
The observed trend is exactly the same of that recorded by feeding air at the cathode (see Figure $4 a, b$ ). Since the cell based on the cathode catalyst that was rich in Ni showed a poor performance, this cell was not investigated further; however, the membrane electrode assemblies (MEAs) based on $\mathrm{Pt}_{1} \mathrm{Ni}_{1} / \mathrm{C}$ and $\mathrm{Pt}_{3} \mathrm{Ni}_{2} / \mathrm{C}$ were tested at $80{ }^{\circ} \mathrm{C}$ under low humidification (50\% R.H., 1.5 bar abs $_{\text {ab }}$ ) conditions (Figure $5 \mathrm{a}$ ) and compared to the one equipped with the commercial $\mathrm{Pt} / \mathrm{C}$ catalyst.

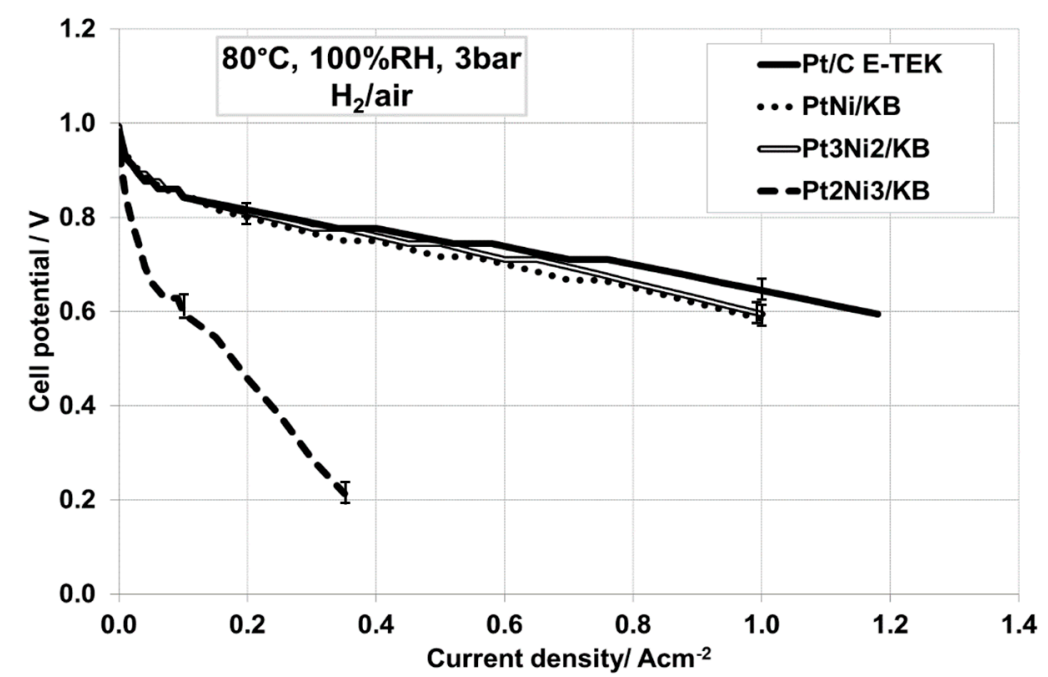

(a)

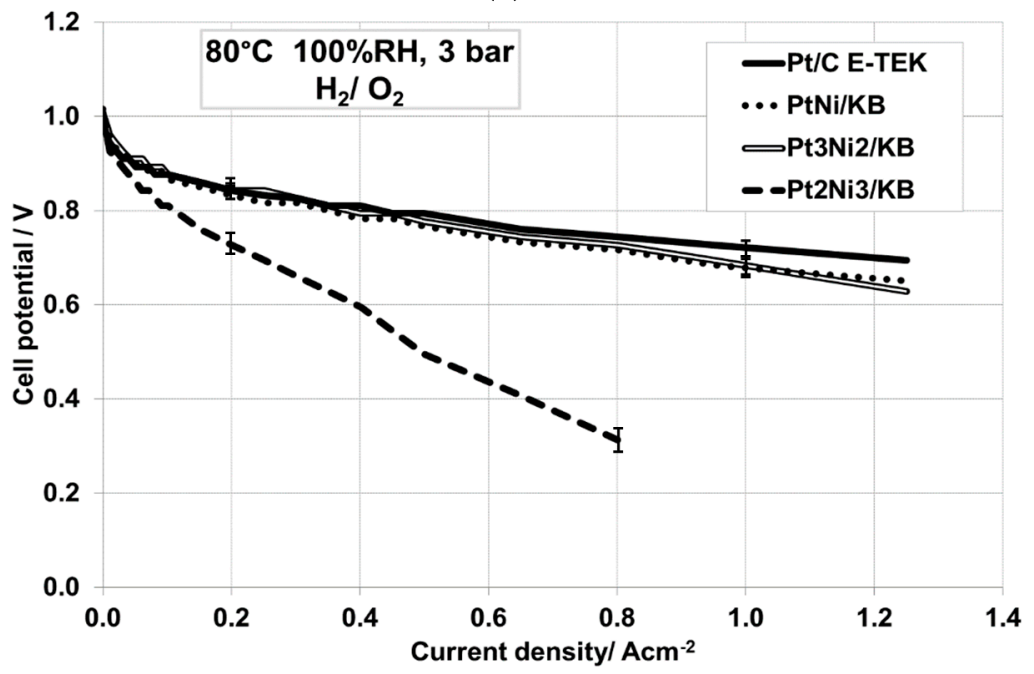

(b)

Figure 4. Polarization curves in (a) $\mathrm{H}_{2}$ /air and (b) $\mathrm{H}_{2} / \mathrm{O}_{2}$ among the MEAs equipped with the different cathodic PtNi catalysts and the benchmark Pt/C catalyst at $80{ }^{\circ} \mathrm{C}, 100 \%$ relative humidity $(\mathrm{RH}), 3$ bar $_{\mathrm{abs}}$.

At low $\mathrm{RH}$, the MEA based on the Pt-rich catalyst $\left(\mathrm{Pt}_{3} \mathrm{Ni}_{2} / \mathrm{C}\right)$ showed a lower voltage loss in the activation region, compared to the equimolar bimetallic catalyst and benchmark $\mathrm{Pt} / \mathrm{C}$. The slightly better behavior of this catalyst could be ascribed to a proper composition or to a lower crystallite size compared to the equimolar PtNi sample. On one hand, the Pt crystallite size of $\mathrm{Pt}_{3} \mathrm{Ni}_{2} / \mathrm{KB}(2.3 \mathrm{~nm}$, Table 1) is slightly lower than PtNi/KB $(2.7 \mathrm{~nm})$. A smaller particle size means larger electrochemical surface area and more available active sites for the oxygen reduction. However, since negligible differences were observed between PtNi catalysts under full humidification, the different surface characteristics could also play a role in enhancing the catalytic activity of the catalyst. The most 
relevant characteristic of $\mathrm{Pt}_{3} \mathrm{Ni}_{2} / \mathrm{KB}$ is its larger amount of metallic $\mathrm{Ni}(19.7 \%)$ as revealed by XPS, which could contribute to oxygen adsorption on the Pt surface (by geometric and electronic effects). The polarization curves recorded at $95{ }^{\circ} \mathrm{C}$ under low R.H. conditions (Figure 5b) confirm a better catalytic activity of the Pt-rich bimetallic catalyst compared to the other ones. In this case, the PtNi (1:1) also shows a higher catalytic activity than the $\mathrm{Pt} / \mathrm{C}$, indicating the beneficial effect of $\mathrm{Ni}$ in enhancing the kinetics of the oxygen reduction reaction, in particular under low humidification. The proton availability related to the water content has, of course, an effect on the kinetics. A significant reduction of relative humidity caused a decrease of proton availability and a consequent increase of the activation barrier for the ORR. This aspect could be associated to both membrane and ionomer dry-out, resulting in a lower availability of protons at the catalyst-ionomer electrolyte interface. The presence of $\mathrm{Ni}$, in its oxidized forms, could help to reduce these constraints.

Table 3. Summary of the fuel cell results.

\begin{tabular}{|c|c|c|c|c|}
\hline Operating Conditions & Sample Catalyst & $\mathrm{OCV}, \mathrm{V}$ & R Cell, $\Omega \cdot \mathrm{cm}^{2}$ & $\mathrm{E} @ 500 \mathrm{~mA} \cdot \mathrm{cm}^{-2}, \mathrm{~V}$ \\
\hline \multirow{4}{*}{$\begin{array}{c}80{ }^{\circ} \mathrm{C}, 100 \% \mathrm{RH}, \\
3 \text { bar }_{\text {abs }}, \mathrm{H}_{2} \text { /air }\end{array}$} & $\mathrm{Pt} / \mathrm{C}$ E-TEK & 0.976 & 0.067 & 0.744 \\
\hline & $\mathrm{PtNi} / \mathrm{KB}$ & 0.982 & 0.127 & 0.717 \\
\hline & $\mathrm{Pt}_{3} \mathrm{Ni}_{2} / \mathrm{KB}$ & 0.993 & 0.107 & 0.744 \\
\hline & $\mathrm{Pt}_{2} \mathrm{Ni}_{3} / \mathrm{KB}$ & 0.943 & 0.250 & - \\
\hline \multirow{4}{*}{$\begin{array}{c}80{ }^{\circ} \mathrm{C}, 100 \% \mathrm{RH} \\
3 \text { bar }_{\text {abs }}, \mathrm{H}_{2} / \mathrm{O}_{2}\end{array}$} & $\mathrm{Pt} / \mathrm{C}$ E-TEK & 0.993 & 0.070 & 0.794 \\
\hline & $\mathrm{PtNi} / \mathrm{KB}$ & 1.015 & 0.118 & 0.767 \\
\hline & $\mathrm{Pt}_{3} \mathrm{Ni}_{2} / \mathrm{KB}$ & 1.009 & 0.097 & 0.777 \\
\hline & $\mathrm{Pt}_{2} \mathrm{Ni}_{3} / \mathrm{KB}$ & 1.009 & 0.199 & 0.495 \\
\hline \multirow{3}{*}{$\begin{array}{c}80{ }^{\circ} \mathrm{C}, 50 \% \mathrm{RH}, \\
1.5 \text { bar }_{\text {abs }}, \mathrm{H}_{2} / \mathrm{O}_{2}\end{array}$} & $\mathrm{Pt} / \mathrm{C}$ E-TEK & 0.993 & 0.082 & 0.761 \\
\hline & $\mathrm{PtNi} / \mathrm{KB}$ & 0.999 & 0.139 & 0.733 \\
\hline & $\mathrm{Pt}_{3} \mathrm{Ni}_{2} / \mathrm{KB}$ & 1.026 & 0.103 & 0.761 \\
\hline \multirow{3}{*}{$\begin{array}{l}95{ }^{\circ} \mathrm{C}, 50 \% \mathrm{RH}, \\
2 \text { bar }_{\mathrm{abs}}, \mathrm{H}_{2} / \mathrm{O}_{2}\end{array}$} & $\mathrm{Pt} / \mathrm{C}$ E-TEK & 0.960 & 0.075 & 0.744 \\
\hline & $\mathrm{PtNi} / \mathrm{KB}$ & 1.000 & 0.112 & 0.733 \\
\hline & $\mathrm{Pt}_{3} \mathrm{Ni}_{2} / \mathrm{KB}$ & 1.000 & 0.084 & 0.777 \\
\hline
\end{tabular}

Figure 6 summarizes the cell voltage corrected by the ohmic drop (iR-free) at $0.5 \mathrm{~A} \cdot \mathrm{cm}^{-2}$ for the three most performing catalysts at the different operating conditions used. Although a comparison with the literature is not easy due to the different conditions and materials (also in terms of catalyst loading) used, we can observe that the performance is similar to that recorded in Refs. [8,30,31], where potential values (iR-free) around $0.8 \mathrm{~V}$ are reported at $0.5 \mathrm{~A} \cdot \mathrm{cm}^{-2}$. Mani et al. [8] reported a cell voltage lower than $0.75 \mathrm{~V}$ for a PtNi/C cathode-based MEA at $80{ }^{\circ} \mathrm{C}, 100 \% \mathrm{RH}, \mathrm{H}_{2} / \mathrm{O}_{2}$ and Pt loading close to $0.1 \mathrm{mg} \cdot \mathrm{cm}^{-2}$ at a much lower current density of $0.002 \mathrm{~A} \cdot \mathrm{cm}^{-2}$. Da Silva et al. [31] employed a higher Pt loading of $0.5 \mathrm{mg} \cdot \mathrm{cm}^{-2}$ for several PtNi catalysts. The best-performing one achieved a cell voltage of $0.34 \mathrm{~V}$ at $1000 \mathrm{~A} \cdot \mathrm{g}_{\mathrm{Pt}}{ }^{-1}$, equivalent to $0.5 \mathrm{~A} \cdot \mathrm{cm}^{-2}$ (reported in Figure 6), but not iR-corrected, at $80^{\circ} \mathrm{C}$ and fully humidified $\mathrm{H}_{2} / \mathrm{O}_{2}$ streams. The series resistance was quite high $\left(0.94 \Omega \cdot \mathrm{cm}^{2}\right)$ and, after iR correction, the cell voltage is close to $0.81 \mathrm{~V}$. Peng et al. [30] have recently reported PEFC results for a PtNi catalyst performing $0.8 \mathrm{~V}$ at $0.5 \mathrm{~A} \cdot \mathrm{cm}^{-2}$ with $75 \% \mathrm{RH}$ at $80{ }^{\circ} \mathrm{C}$. Han et al. [29] obtained very promising results using dealloyed Pt-Ni catalysts. The dealloying method is a useful approach to obtain Pt-rich surface or core-shell structures for bimetallic catalysts [32]. They showed high performance and durability using a family of dealloyed Pt-Ni catalysts for the ORR $[29,32]$. The behavior at $80^{\circ} \mathrm{C}$ and low current density were comparable to that observed in the present work using $\mathrm{Pt}_{3} \mathrm{Ni}_{2} / \mathrm{C}_{\text {and }}$ $\mathrm{Pt}_{1} \mathrm{Ni}_{1} / \mathrm{C}$ catalysts, although $0.2 \mathrm{mg} \cdot \mathrm{cm}^{-2} \mathrm{Pt}$ loading was used in our investigation compared to $0.1 \mathrm{mg} \cdot \mathrm{cm}^{-2}$ reported in Ref. [29]. At high current densities, the performance reached by Han et al. [29] was higher compared to that obtained in the present analysis with our Pt-Ni catalysts; however, it must be taken into account that a thinner membrane was employed in Ref. [29], which produced a lower cell resistance. 
Furthermore, in order to increase the stability of the catalysts, a post-dealloying thermal annealing is usually applied [29,32]. This procedure produces an increased $\mathrm{Pt}$ surface diffusion rate promoting an improved Pt-skin layer on the bimetallic catalyst [29,32]. Furthermore, the dealloying process, in particular starting from high initial non-noble atom concentration, generates porous structure, clearly visible by scanning tunneling electron microscopy (STEM) [29,32]. In our approach, the thermal treatment was carried out before the acid leaching procedure, and, in the case of the $\mathrm{Pt}_{1} \mathrm{Ni}_{1} / \mathrm{C}$ catalyst, produced a more ordered alloy structure, as observed from the XRD pattern. From TEM images reported in Figure 2 at low magnification, porous nanoparticles are not detectable, and, although a Pt enrichment of the surface can be envisaged from XPS, the formation of a Pt skin layer should be confirmed by using other techniques. In terms of performance, the formation of a more ordered crystallographic structure for the $\mathrm{Pt}_{1} \mathrm{Ni}_{1} / \mathrm{C}$ catalyst did not translate into a better behavior; however, this, together with the possible formation of a Pt skin layer, could be the reason of the improved stability obtained for the cell based on this catalyst (see discussion below). This was also reported in a recently published paper [33], in which the conversion of PtNi nanoparticles from a disordered solid solution to an ordered intermetallic compound led to an enhanced durability and better ORR activity. In our case, the ORR activity was found to be better for the $\mathrm{Pt}_{3} \mathrm{Ni}_{2}$ disordered solid solution compared to the ordered $\mathrm{Pt}_{1} \mathrm{Ni}_{1}$, more likely due to a major presence of $\mathrm{Pt}$ in the catalyst.

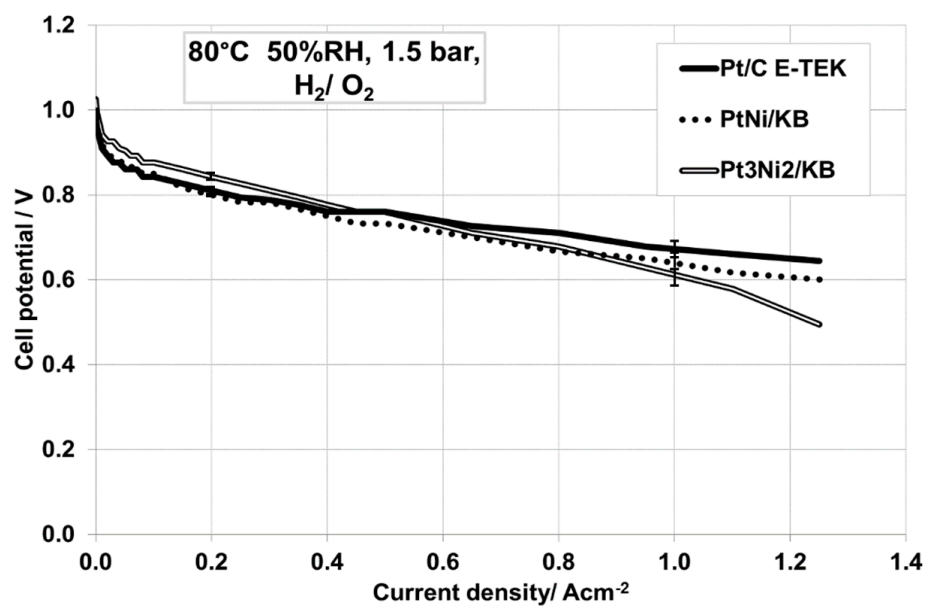

(a)

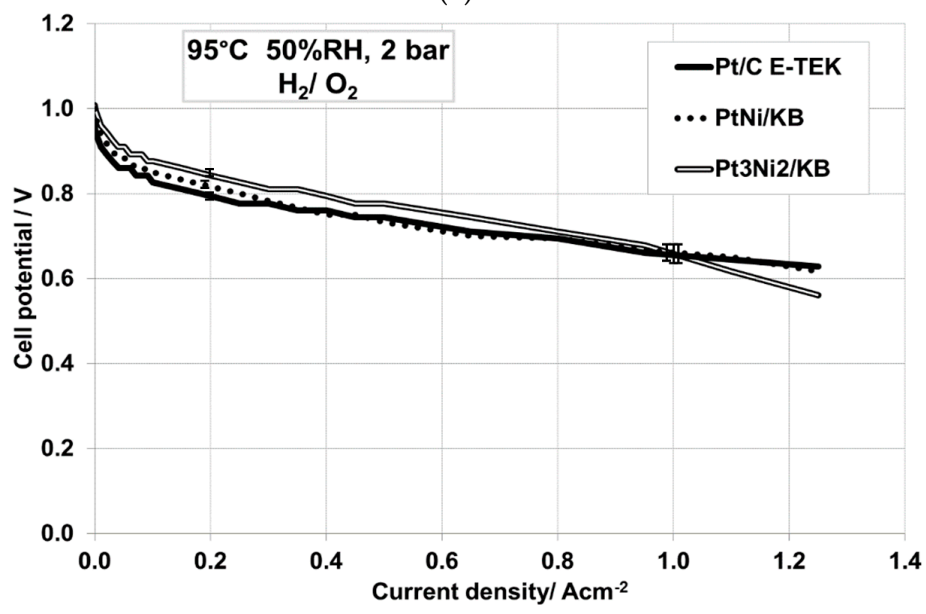

(b)

Figure 5. Polarization curves among the MEAs equipped with the different cathodic PtNi catalysts and the benchmark Pt/C catalyst at different operative conditions: (a) $80{ }^{\circ} \mathrm{C}, 50 \%$ R.H., 1.5 bar $\mathrm{abs}_{2}, \mathrm{H}_{2} / \mathrm{O}_{2}$; and (b) $95^{\circ} \mathrm{C}, 50 \%$ R.H., 2 bar $_{\text {abs }}, \mathrm{H}_{2} / \mathrm{O}_{2}$. 


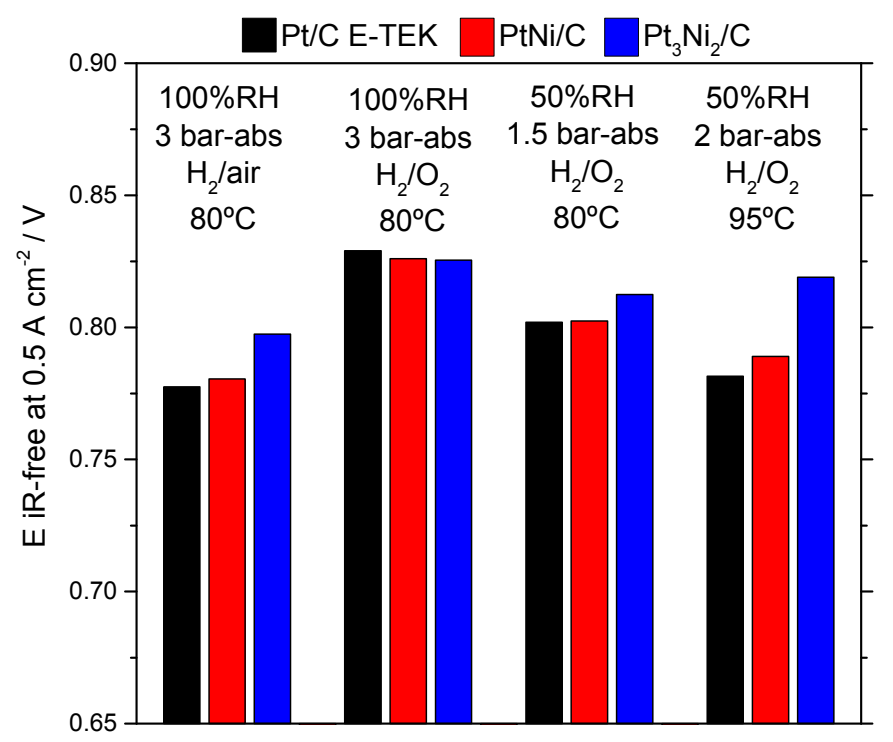

Figure 6. Cell potential (iR-free) at $0.5 \mathrm{~A} \cdot \mathrm{cm}^{-2}$ for the MEAs equipped with $\mathrm{PtNi} / \mathrm{C}$ (red), $\mathrm{Pt}_{3} \mathrm{Ni}_{2} / \mathrm{C}$ (blue) and Pt/C E-TEK (black) catalysts at the cathode under the operating conditions described.

Accelerated degradation tests (ADTs), i.e., 15,000 step cycles (steps $0.6-1.2 \mathrm{~V}$, cycle time $6 \mathrm{~s}, \mathrm{H}_{2}-\mathrm{N}_{2}$ ), were carried out for all catalysts at $80^{\circ} \mathrm{C}, 100 \%$ R.H., 1.5 bar $_{\text {abs }}$. A milder protocol, i.e., $0.6-0.9 \mathrm{~V}$ cycling, was first carried out, but the differences in performance before and after the test were found to be almost negligible, as observed in Figure S1 of the supporting information. After the degradation test, polarization curves were carried out under the same conditions feeding oxygen at the cathode (Figure 7). From the analysis of the curves recorded before and after the degradation test, it appears that the equimolar bimetallic catalyst $\left(\mathrm{Pt}_{1} \mathrm{Ni}_{1}\right)$ shows the best stability since the polarization profile does not change much after the ADT, especially in the low current density region.

The benchmark catalyst shows the largest losses in performance, as can be derived from the histograms reported in Figure 8, which summarizes the potential losses at two values of current density (of interest for what concerns catalytic activity and practical application) of the various MEAs after the ADT. Figure 8 shows the cell potential at $200 \mathrm{~mA} \cdot \mathrm{cm}^{-2}$ and $950 \mathrm{~mA} \cdot \mathrm{cm}^{-2}$ for the three MEAs subjected to the ADT. The MEA based on the benchmark Pt catalyst showed the largest potential losses at low current density ( $8 \%$ ) after the ADT while the $\mathrm{Pt}_{1} \mathrm{Ni}_{1} / \mathrm{C}$-based MEA was the most stable ( $2 \%$ and $12.5 \%$ voltage losses at $200 \mathrm{~mA} \cdot \mathrm{cm}^{-2}$ and $950 \mathrm{~mA} \cdot \mathrm{cm}^{-2}$, respectively). In all cases, the latter MEA presented the highest cell potential after the ADT among the investigated ones both at 200 and $950 \mathrm{~mA} \cdot \mathrm{cm}^{-2}$. Cyclic voltammetry analyses carried out before and after the ADT (not shown) allowed the determination of the electrochemical active surface area (ECSA) that is reported in Table 4, together with the crystallite size determined by XRD at the BoL and EoL. The values show that all catalysts are affected by significant particle sintering; the crystallite size increases from three to five times after the tests, causing a relevant decrease of ECSA to almost half the initial value. However, the catalyst showing a more ordered crystallographic structure appears less affected by sintering phenomena during the ADT [33]. It is worth mentioning that the ECSA is higher for the PtNi/C catalysts, related to their smaller particle size as revealed by XRD and TEM analyses. No significant change in the ECSA at the BoL may be attributed to the different content in $\mathrm{Ni}$ between $\mathrm{PtNi} / \mathrm{KB}$ and $\mathrm{Pt}_{3} \mathrm{Ni}_{2} / \mathrm{KB}$. Da Silva et al. reported an increased ECSA when introducing Ni caused by the decrease of Pt-Pt bond distance (geometric effect) and the increase of the 5d-band vacancy (electronic effect) [31]. 


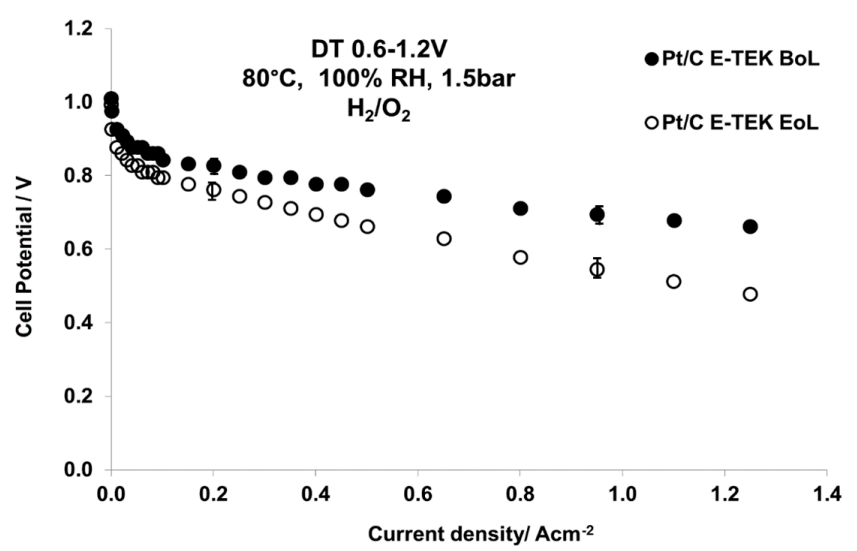

(a)

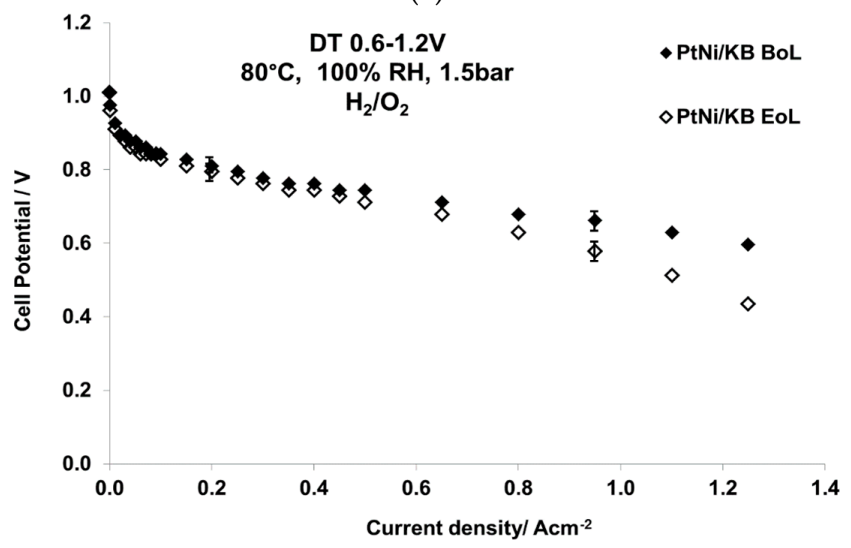

(b)

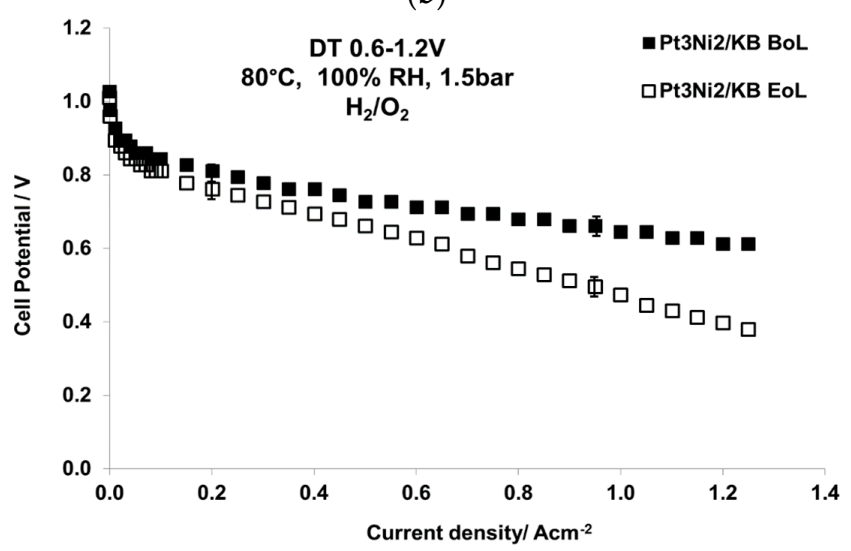

(c)

Figure 7. Polarization curves before and after the ADT for the MEAs based on carbon supported (a) Pt; (b) $\mathrm{Pt}_{1} \mathrm{Ni}_{1}$; and (c) $\mathrm{Pt}_{3} \mathrm{Ni}_{2}$ at $80{ }^{\circ} \mathrm{C}, 100 \%$ R.H., 1.5 bar $_{\text {abs }}, \mathrm{H}_{2} / \mathrm{O}_{2}$.

To confirm this conjecture, XRD and TEM analyses were carried out after the ADTs; the XRD patterns and the TEM images after the ADTs are reported in Figure 9. A dramatic increase of crystallite size can be observed in the XRD patterns, together with a significant shift of the peaks towards lower Bragg angles, which is an indication of a dealloying phenomenon. From TEM micrographs, we can derive that a particle sintering occurred together with a leaching of particles due to carbon corrosion (as can be observed in Figure S2 of the supplementary information). Thus, it appears that this preparation procedure is not suitable to obtain stable catalysts. Recently, Pt-Ni nanocage (PNC) catalysts were synthesized by a solvothermal method and investigated in PEFCs in terms of performance and stability [30]. The PNC experienced slight agglomeration and some edge loss after 
cycling ( $30 \mathrm{~K}$ cycles in the range $0.6 \mathrm{~V}$ to $1.0 \mathrm{~V}$ ). However, the majority of the particles retained their cage structure. In our case, large agglomeration and particles losses were observed indicating that the high temperature treatment is not enough to stabilize the PtNi alloy, in particular under these severe testing conditions ( $0.6-1.2 \mathrm{~V}$ cycling). Under milder conditions $(0.6-0.9 \mathrm{~V}$ cycling) the results envisaged lower stability constraints (see Figure S1 in the supplementary information).

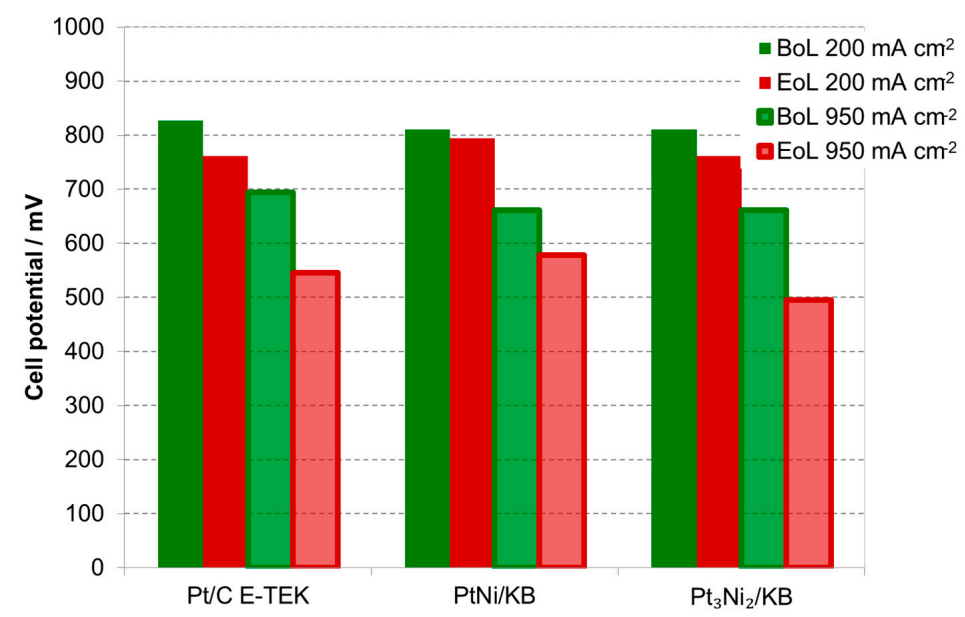

Figure 8. Histogram reporting the cell potential at 200 and $900 \mathrm{~mA} \cdot \mathrm{cm}^{-2}$ for the MEAs based on the different cathodic catalysts before and after the ADT.

Table 4. Electrochemical active surface area and crystallite size at the beginning and end of life for the different MEAs.

\begin{tabular}{cccc}
\hline Sample Catalyst & Status & ECSA, $\mathbf{~ m}^{\mathbf{2}} \cdot \mathbf{g}^{-\mathbf{1}}$ & Crystallite Size, $\mathbf{n m}$ \\
\hline \multirow{2}{*}{ Pt/C E-TEK } & BoL & 22 & 5 \\
& EoL & 9 & 16 \\
\hline \multirow{2}{*}{$\mathbf{P t N i} / \mathbf{K B}$} & BoL & 44 & 2.7 \\
& EoL & 18 & 12 \\
\hline \multirow{2}{*}{$\mathbf{P t}_{3} \mathbf{N i}_{2} / \mathbf{K B}$} & BoL & 42 & 2.3 \\
& EoL & 12 & 15 \\
\hline
\end{tabular}

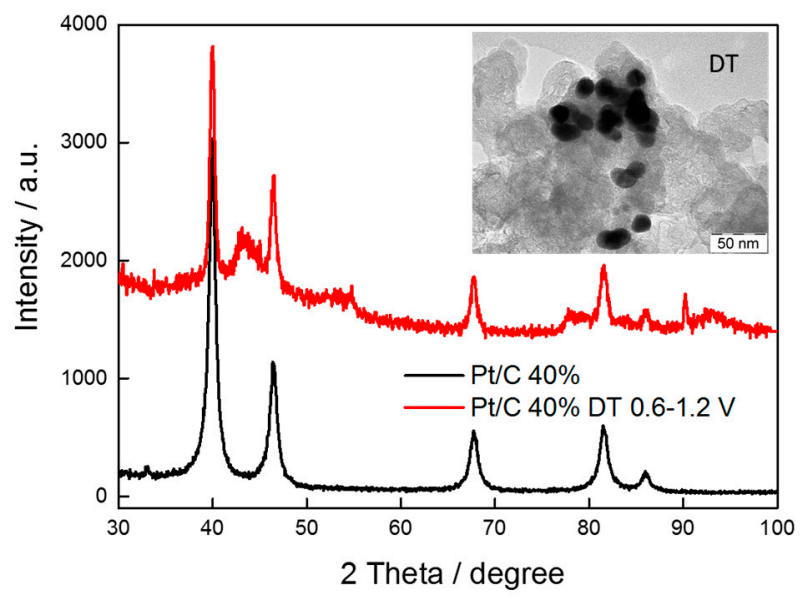

(a)

Figure 9. Cont. 


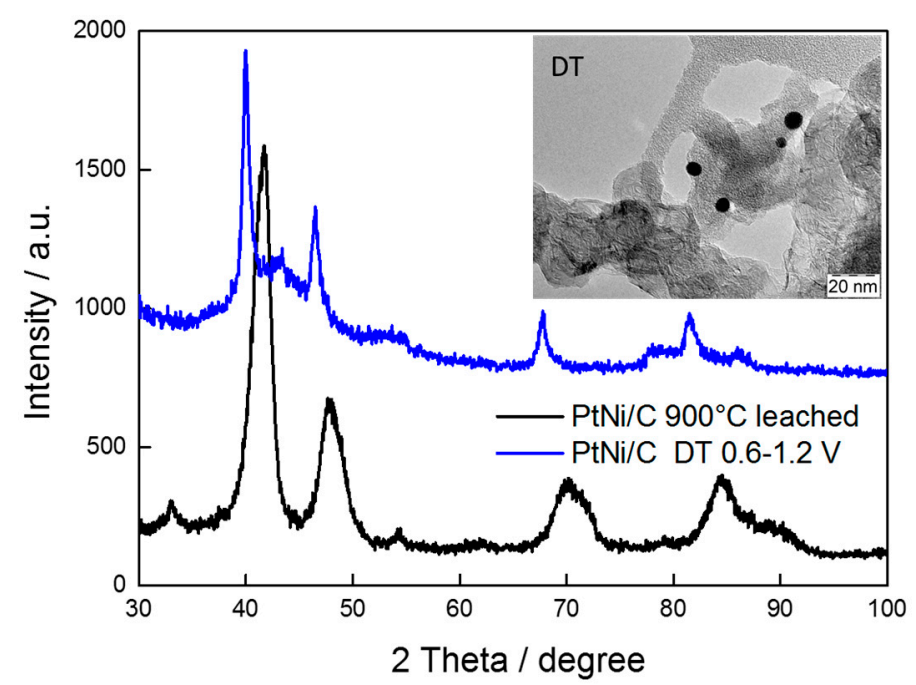

(b)

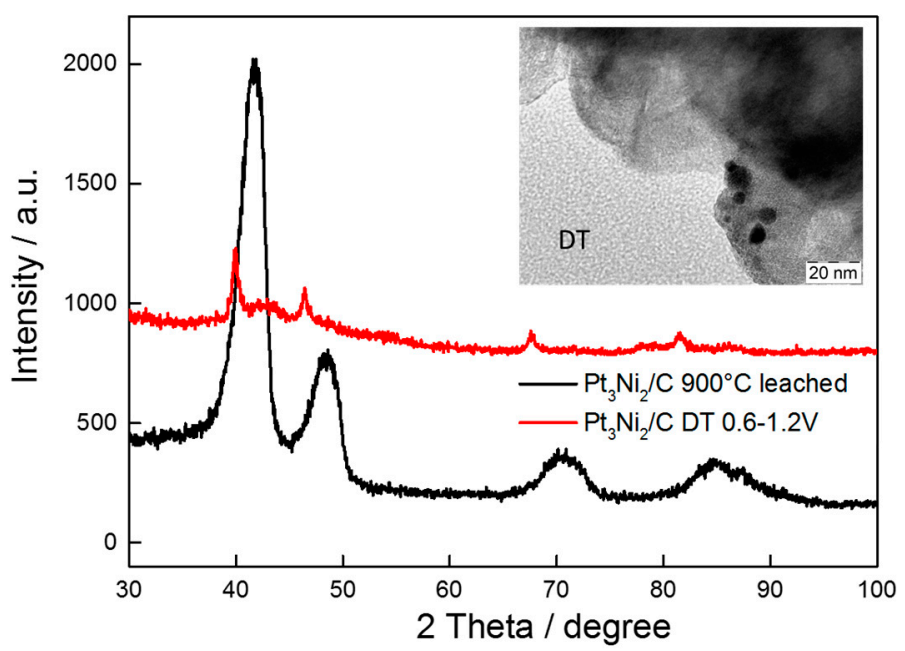

(c)

Figure 9. XRD patterns of carbon supported (a) Pt/C; (b) PtNi1C; (c) $\mathrm{Pt}_{3} \mathrm{Ni}_{2} / \mathrm{C}$ catalysts before and after the ADT. The inset shows the TEM image of the catalyst after the ADT.

\section{Materials and Methods}

\subsection{Catalyst Preparation and Physico-Chemical Characterization}

Carbon supported Pt-Ni catalysts with different atomic Pt:Ni ratios (1:1, 3:2 and 2:3) were prepared by the formic acid reduction [34] method using a $0.5 \mathrm{M} \mathrm{HCOOH}$ concentration. Ketjenblack (KB) from AzkoNobel was used as the carbon support. A suspension of $\mathrm{KB}$ in $0.5 \mathrm{M}$ formic acid solution was heated at $80{ }^{\circ} \mathrm{C}$. Chloroplatinic acid $\left(\mathrm{H}_{2} \mathrm{PtCl}_{6} \cdot 6 \mathrm{H}_{2} \mathrm{O}\right)$ and Nickel nitrate $\left(\mathrm{Ni}\left(\mathrm{NO}_{3}\right)_{2} \cdot 6 \mathrm{H}_{2} \mathrm{O}\right)$ solutions were slowly added to the carbon suspension. The slurry was maintained at $80^{\circ} \mathrm{C}$ for $5 \mathrm{~h}$. The suspension was left to cool at room temperature and the solid filtered and dried in an oven at $100{ }^{\circ} \mathrm{C}$ for $2 \mathrm{~h}$. The total nominal metal concentration was $50 \mathrm{wt} \%$. The as-prepared catalysts were thermally treated at $900{ }^{\circ} \mathrm{C}$ in inert (Ar) atmosphere and a related structural analysis was carried out. A pre-leaching procedure at $80{ }^{\circ} \mathrm{C}$ in $0.5 \mathrm{M} \mathrm{HClO}_{4}$ was carried out for the PtNi catalysts after the thermal reduction. Physical properties such as the lattice parameter and the average crystallite size were determined by using a powder X-ray diffraction (XRD) technique. XRD patterns were obtained 
using a Philips $\mathrm{X}^{\prime}$ Pert $\mathrm{X}$-ray diffractometer equipped with a $\mathrm{Cu} / \mathrm{K} \alpha$ source operating at $40 \mathrm{kV}$ and $30 \mathrm{~mA}$. Scans were carried out at $2^{\circ} \mathrm{min}^{-1}$ for $2 \theta$ values between $10^{\circ}$ and $100^{\circ}$.

The catalyst composition of the different powder samples was determined by energy dispersive X-ray analysis (EDX) using an FEI XL 30-Feg SEM-EDX instrument (FEI, Eindhoven, The Netherlands). Transmission electron micrographs (TEM) of the PtNi catalysts were obtained using a Philips CM12 transmission electron microscope (Philips, Eindhoven, The Netherlands) with spatial resolution of $0.2 \mathrm{~nm}$. For this analysis, the catalysts were ultrasonically dispersed in isopropyl alcohol and deposited onto copper grids covered with carbon films. To obtain the electron micrographs, the catalyst samples were finely grinded and an amount of 200 metal particles was measured to obtain a particle size distribution histogram for each catalyst.

X-ray photoelectron spectroscopy (XPS) measurements was carried out using a Physical Electronics (PHI) 5800-01 spectrometer (Chanhassen, MN, USA). A monochromatic Al K $\alpha$ X-ray source was used at a power of $350 \mathrm{~W}$. Spectra were obtained with pass energies of $58.7 \mathrm{eV}$ for elemental analysis (composition) and $11.75 \mathrm{eV}$ for the determination of the oxidation states. The pressure in the analysis chamber of the spectrometer was $1 \times 10^{-9}$ Torr during the measurements. The $\mathrm{Ag} 3 \mathrm{~d}_{5 / 2}$ peak of an $\mathrm{Ag}$ foil was taken, after argon sputtering, for checking the calibration of the binding energy (BE) scale. The quantitative evaluation of each peak was obtained by dividing the integrated peak area by atomic sensitivity factors, which were calculated from the ionization cross-sections, the mean free electron escape depth and the measured transmission functions of the spectrometer. XPS data have been interpreted by using the on-line library of oxidation states implemented in the PHI MULTIPAK 6.1 software (version 6.1, Physical Electronics, Chanhassen, MN, USA) and the PHI Handbook of X-ray photoelectron spectroscopy [35].

\subsection{Electrodes and MEA Preparation}

To evaluate the performance of the electro-catalysts, different electrodes were prepared by using as cathode electro-catalyst the $\mathrm{Pt}-\mathrm{Ni}$ alloys previously prepared. For the sake of comparison, a commercial $40 \% \mathrm{Pt} / \mathrm{C}$ E-TEK was selected to investigate the performance and durability in order to have similar electrode features (i.e., thickness, $\mathrm{Pt}: \mathrm{C}$ ratio, etc.). At the anode side, an in-house prepared $\mathrm{Pt} / \mathrm{C}$ catalyst was used in all experiments [36]. The catalytic ink was prepared by mixing, in an ultrasonic bath, the electro-catalyst with a $33 \mathrm{wt} \%$ of dry Nafion (5 wt \% hydroalcoholic solution) as a ionomer [37]. For catalyst layer preparation a $20 \mathrm{wt} \%$ of ammonium carbonate (Carlo Erba, Milan, Italy) was used as a pore-former. The catalytic ink was deposited onto a gas diffusion layer SGL25BC, by a standardised spray technique [38]. A Pt loading of $0.2 \mathrm{mg} / \mathrm{cm}^{2}$ was used for both electrodes. The MEAs were prepared by hot pressing, assembling the electrodes with a commercial NR212 membrane at $125^{\circ} \mathrm{C}$.

\subsection{Electrochemical Studies}

Electrochemical studies were performed in a $25 \mathrm{~cm}^{2}$ single cell, in a temperature range between $80^{\circ} \mathrm{C}$ and $95^{\circ} \mathrm{C}$, at a pressure ranging from 3 to $1.5 \mathrm{bar}_{\text {abs }}$ and at different relative humidities (R.H.), from $100 \%$ to $50 \%$. The cell was fed with $\mathrm{H}_{2}$ as fuel and air or $\mathrm{O}_{2}$ as oxidant in order to evaluate simultaneously the single cell performance and the catalytic activity for the ORR. The flow rates were varied to have constant stoichiometry of 2 and 1.5 for oxidant and fuel, respectively. The single cell performance was investigated by steady-state galvanostatic measurements. The cell was connected to a fuel cell test station including an HP6051A electronic load. For the cyclic voltammetry (CV) studies, the single cell was connected to a Potentiostat/Galvanostat PGSTAT30 AUTOLAB Metrohm (Utrecht, The Netherlands), equipped with a frequency response analyzer (FRA) module and a $20 \mathrm{~A}$ current booster. Humidified hydrogen was fed to the anode side, which operated as both counter and reference electrode, whereas humidified nitrogen was fed to the cathode side (working electrode) at 1 bar $_{\text {abs. }}$. The sweep rate was $50 \mathrm{mVs}^{-1}$. The electrochemical active surface area was determined by integration of the $\mathrm{CV}$ profile in the hydrogen adsorption region after correction for the double layer capacitance. Data were not corrected for ohmic drop and hydrogen cross-over. The cell resistance 
was measured at open circuit voltage by using a Hewlett-Packard (type HP 4338B) milli-ohmmeter (Hewlett-Packard, Palo Alto, CA, USA), working at a frequency of $1 \mathrm{kHz}$. Moreover, in order to verify the electro-catalysts stability, accelerated degradation tests, at $80{ }^{\circ} \mathrm{C}, 100 \%$ R.H., 1 bar abs $\mathrm{H}_{2}-\mathrm{N}_{2}$, were carried out by cycling the cell potential between $0.6 \mathrm{~V}$ and $1.2 \mathrm{~V}$. The performance analyses were carried out by comparing electrochemical and physico-chemical parameters at the beginning of life $(\mathrm{BoL})$ and end of life (EoL).

\section{Conclusions}

PtNi electrocatalysts were prepared by the formic acid method and successive thermal and leaching treatments in order to assess the best composition in terms of catalytic activity, fuel cell performance and stability. The catalyst characterized by a larger $\mathrm{Pt}$ content $\left(\mathrm{Pt}_{3} \mathrm{Ni}_{2} / \mathrm{C}\right)$ presented the highest catalytic activity during the polarization curves (lower potential losses in the activation region) among the synthesized and reference commercial catalysts at high temperature and low humidification conditions typical of automotive applications. Accelerated degradation tests carried out, by using a severe cycling protocol, on the MEAs equipped with the bimetallic in-house PtNi catalysts and the benchmark $\mathrm{Pt} / \mathrm{C}$ demonstrated that the equimolar PtNi catalyst was the most stable formulation showing the best performance at the end of life $\left(0.58 \mathrm{~V}\right.$ at $\left.950 \mathrm{~mA} \cdot \mathrm{cm}^{-2}\right)$. Thus, it appeared that both the crystalline features (i.e., ordered crystallographic phase and $2.7 \mathrm{~nm}$ as size) and a larger presence of $\mathrm{Ni}$ contributed to the enhanced performance of the $50 \% \mathrm{PtNi} / \mathrm{C}$ after the ADT, although a significant loss of activity and ECSA were recorded due to carbon corrosion, particle sintering and Ni dealloying.

Supplementary Materials: The following are available online at www.mdpi.com/1996-1944/10/3/317/s1.

Acknowledgments: The research leading to these results has received funding from the European Union's Seventh Framework Programme (FP7/2007-2013) for Fuel Cell and Hydrogen Joint Technology Initiative under Grant No. 303452 (IMPACT).

Author Contributions: A.S.A. and I.G. conceived and designed the catalysts and experiments; S.C.Z. prepared the catalysts; A.S. performed the electrochemical experiments; D.S. and V.B. analyzed the data; D.S. contributed analysis tools; and V.B. wrote the paper.

Conflicts of Interest: The authors declare no conflict of interest.

\section{References}

1. Liu, Y.; Lehnert, W.; Janßen, H.; Samsun, R.C.; Stolten, D. A review of high-temperature polymer electrolyte membrane fuel-cell (HT-PEMFC)-based auxiliary power units for diesel-powered road vehicles. J. Power Source 2016, 311, 91-102. [CrossRef]

2. Gasteiger, H.A.; Kocha, S.S.; Sompalli, B.; Wagner, F.T. Activity benchmarks and requirements for Pt, Pt-alloy, and non-Pt oxygen reduction catalysts for PEMFCs. Appl. Catal. B Environ. 2005, 56, 9-35. [CrossRef]

3. Stassi, A.; Gatto, I.; Monforte, G.; Baglio, V.; Passalacqua, E.; Antonucci, V.; Aricò, A.S. The effect of thermal treatment on structure and surface composition of PtCo electro-catalysts for application in PEMFCs operating under automotive conditions. J. Power Source 2012, 208, 35-45. [CrossRef]

4. Wu, H.; Wexler, D.; Wang, G. PtxNi alloy nanoparticles as cathode catalyst for PEM fuel cells with enhanced catalytic activity. J. Alloys Compd. 2009, 488, 195-198. [CrossRef]

5. Hyun, K.; Lee, J.H.; Yoon, C.W.; Kwon, Y. The effect of platinum based bimetallic electrocatalysts on oxygen reduction reaction of proton exchange membrane fuel cells. Int. J. Electrochem. Sci. 2013, 8, 11752-11767.

6. Zignani, S.C.; Antolini, E.; Gonzalez, E.R. Stability of Pt-Ni/C (1:1) and Pt/C electrocatalysts as cathode materials for polymer electrolyte fuel cells: Effect of ageing tests. J. Power Source 2009, 191, 344-350. [CrossRef]

7. Stassi, A.; Gatto, I.; Baglio, V.; Passalacqua, E.; Aricò, A.S. Investigation of Pd-based electrocatalysts for oxygen reduction in PEMFCs operating under automotive conditions. J. Power Source 2013, 222, 390-399. [CrossRef] 
8. Mani, P.; Srivastava, R.; Strasser, P. Dealloyed binary PtM3 $(\mathrm{M}=\mathrm{Cu}, \mathrm{Co}, \mathrm{Ni})$ and ternary PtNi3M $(\mathrm{M}=\mathrm{Cu}$, $\mathrm{Co}, \mathrm{Fe}, \mathrm{Cr}$ ) electrocatalysts for the oxygen reduction reaction: Performance in polymer electrolyte membrane fuel cells. J. Power Source 2011, 196, 666-673. [CrossRef]

9. Jayasayee, K.; Van Veen, J.A.R.; Manivasagam, T.G.; Celebi, S.; Hensen, E.J.M.; de Bruijn, F.A. Oxygen reduction reaction (ORR) activity and durability of carbon supported $\mathrm{PtM}(\mathrm{Co}, \mathrm{Ni}, \mathrm{Cu})$ alloys: Influence of particle size and non-noble metals. Appl. Catal. B Environ. 2012, 111-112, 515-526. [CrossRef]

10. Jeon, M.K.; Zhang, Y.; McGinn, P.J. A comparative study of PtCo, PtCr, and PtCoCr catalysts for oxygen electro-reduction reaction. Electrochim. Acta 2010, 55, 5318-5325. [CrossRef]

11. Ishida, M.; Matsutani, K. Development of Pt-Co-Mn Ternary Alloy Catalyst for PEFCs. ECS Trans. 2014, 64, 107-112. [CrossRef]

12. Negro, E.; Monteverde Videla, A.H.A.; Baglio, V.; Aricò, A.S.; Specchia, S.; Koper, G.J.M. Fe-N supported on graphitic carbon nano-networks grown from cobalt as oxygen reduction catalysts for low-temperature fuel cells. Appl. Catal. B Environ. 2015, 166-167, 75-83. [CrossRef]

13. Monteverde Videla, A.H.A.; Osmieri, L.; Specchia, S. Non-noble Metal (NNM) Catalysts for Fuel Cells: Tuning the Activity by a Rational Step-by-Step Single Variable Evolution. In Electrochemistry of N4 Macrocyclic Metal Complexes; Zagal, J.H., Bedioui, F., Eds.; Springer International Publishing Switzerland: Cham, Switzerland, 2016; Volume 1, pp. 69-102.

14. Serov, A.; Artyushkova, K.; Niangar, E.; Wang, C.; Dale, N.; Jaouen, F.; Sougrati, M.-T.; Jia, Q.; Mukerjee, S.; Atanassov, P. Nano-structured non-platinum catalysts for automotive fuel cell application. Nano Energy 2015, 16, 293-300. [CrossRef]

15. Baldizzone, C.; Mezzavilla, S.; Carvalho, H.W.P.; Meier, J.C.; Schuppert, A.K.; Heggen, M.; Galeano, C.; Grunwaldt, J.-D.; Schuth, F.; Mayrhofer, K.J.J. Confined-Space Alloying of Nanoparticles for the Synthesis of Efficient PtNi Fuel-Cell Catalysts. Angew. Chem. Int. Ed. 2014, 53, 14250-14254. [CrossRef] [PubMed]

16. Du, S.; Lu, Y.; Malladi, S.K.; Xu, Q.; Steinberger-Wilckens, R. A simple approach for PtNi-MWCNT hybrid nanostructures as high performance electrocatalysts for the oxygen reduction reaction. J. Mater. Chem. A 2014, 2, 692-698. [CrossRef]

17. Choi, J.; Lee, Y.; Kim, J.; Lee, H. Enhancing stability of octahedral PtNi nanoparticles for oxygen reduction reaction by halide treatment. J. Power Source 2016, 307, 883-890. [CrossRef]

18. Tuaev, X.; Rudi, S.; Petkov, V.; Hoell, A.; Strasser, P. In situ study of atomic structure transformations of Pt-Ni nanoparticle catalysts during electrochemical potential cycling. ACS Nano 2013, 7, 5666-5674. [CrossRef] [PubMed]

19. Wu, J.B.; Yang, H. Synthesis and electrocatalytic oxygen reduction properties of truncated octahedral Pt3Ni nanoparticles. Nano Res. 2011, 4, 72-82. [CrossRef]

20. Li, W.Z.; Haldar, P. Highly active carbon supported core-shell PtNi@Pt nanoparticles for oxygen reduction reaction. Electrochem. Solid State Lett. 2010, 13, B47-B49. [CrossRef]

21. Huang, X.Q.; Zhu, E.B.; Chen, Y.; Li, Y.J.; Chiu, C.Y.; Xu, Y.X.; Lin, Z.Y.; Duan, X.F.; Huang, Y. A facile strategy to $\mathrm{Pt} 3 \mathrm{Ni}$ nanocrystals with highly porous features as an enhanced oxygen reduction reaction catalyst. Adv. Mater. 2013, 25, 2974-2979. [CrossRef] [PubMed]

22. Gan, L.; Heggen, M.; Rudi, S.; Strasser, P. Core-shell compositional fine structures of dealloyed PtxNi1-x nanoparticles and their impact on oxygen reduction catalysis. Nano Lett. 2012, 12, 5423-5430. [CrossRef] [PubMed]

23. van der Vliet, D.; Wang, C.; Debeb, M.; Atanasoski, R.; Markovic, N.M.; Stamenkovic, V.R. Platinum-alloy nanostructured thin film catalysts for the oxygen reduction reaction. Electrochim. Acta 2011, 56, 8695-8699. [CrossRef]

24. Stamenkovic, V.R.; Fowler, B.; Mun, B.S.; Wang, G.F.; Ross, P.N.; Lucas, C.A.; Markovic, N.M. Improved oxygen reduction activity on Pt3Ni (111) via increased surface site availability. Science 2007, 315, 493-497. [CrossRef] [PubMed]

25. Oezaslan, M.; Hasché, F.; Strasser, P. Pt-Based Core-Shell Catalyst Architectures for Oxygen Fuel Cell Electrodes. J. Phys. Chem. Lett. 2013, 4, 3273-3291. [CrossRef]

26. Gan, L.; Cui, C.H.; Rudi, S.; Strasser, P. Core-shell and nanoporous particle architectures and their effect on the activity and stability of Pt ORR electrocatalysts. Top. Catal. 2014, 57, 236-244. [CrossRef] 
27. Chen, S.; Sheng, W.; Yabuuchi, N.; Ferreira, P.J.; Allard, L.F.; Shao-Horn, Y. Origin of oxygen reduction reaction activity on "Pt3Co" nanoparticles: Atomically resolved chemical compositions and structures. J. Phys. Chem. C 2009, 113, 1109-1125. [CrossRef]

28. Stassi, A.; Modica, E.; Antonucci, V.; Aricò, A.S. A Half Cell Study of Performance and Degradation of Oxygen Reduction Catalysts for Application in Low Temperature Fuel Cells. Fuel Cells 2009, 9, 201-208. [CrossRef]

29. Han, B.H.; Carlton, C.E.; Kongkanand, A.; Kukreja, R.S.; Theobald, B.R.; Gan, L.; O'Malley, R.; Strasser, P.; Wagner, F.T.; Shao-Horn, Y. Record activity and stability of dealloyed bimetallic catalysts for proton exchange membrane fuel cells. Energy Environ. Sci. 2015, 8, 258-266. [CrossRef]

30. Peng, X.; Zhao, S.; Omasta, T.J.; Roller, J.M.; Mustain, W.E. Activity and durability of Pt-Ni nanocage electocatalysts in proton exchange membrane fuel cells. Appl. Catal. B Environ. 2017, 203, 927-935. [CrossRef]

31. Da Silva, F.T.; Dalmazzo, V.A.; Becker, M.R.; de Souza, M.O.; de Souza, R.F.; Martini, E.M.A. Effect of Ni proportion on the performance of proton exchange membrane fuel cells using $\mathrm{PtNi} / \mathrm{C}$ electrocatalysts. Ionics 2014, 20, 381-388. [CrossRef]

32. Kuhl, S.; Strasser, P. Oxygen Electrocatalysis on Dealloyed Pt Nanocatalysts. Top. Catal. 2016, 59, $1628-1637$. [CrossRef]

33. Zou, L.; Fan, J.; Zhou, Y.; Wang, C.; Li, J.; Zou, Z.; Yang, H. Conversion of PtNi alloy from disordered to ordered for enhanced activity and durability in methanol-tolerant oxygen reduction reactions. Nano Res. 2015, 8, 2777-2788. [CrossRef]

34. Gonzalez, E.R.; Ticianelli, E.A.; Pinheiro, A.I.N.; Perez, J. Processo de obtenção de catalisador de platina dispersa ancorada em substrato através da redução por ácido. Brazilian Patent INPI-SP No. 00321, 2 September 1997.

35. Moulder, J.F.; Stickle, W.F.; Sobol, P.E.; Bomben, K.D. Handbook of X-ray Photoelectron Spectroscopy; Physical Electronics, Inc.: Eden Prairie, MN, USA, 1995.

36. Arico, A.S.; Stassi, A.; Modica, E.; Ornelas, R.; Gatto, I.; Passalacqua, E.; Antonucci, V. Performance and degradation of high temperature polymer electrolyte fuel cell catalysts. J. Power Source 2008, 178, 525-536. [CrossRef]

37. Gatto, I.; Stassi, A.; Baglio, V.; Carbone, A.; Passalacqua, E.; Aricò, A.S.; Schuster, M.; Bauer, B. Optimization of perfluorosulphonic ionomer amount in gas diffusion electrodes for PEMFC operation under automotive conditions. Electrochim. Acta 2015, 165, 450-455. [CrossRef]

38. Gatto, I.; Saccà, A.; Carbone, A.; Pedicini, R.; Urbani, F.; Passalacqua, E. CO-tolerant electrodes developed with PhosphoMolybdic Acid for Polymer Electrolyte Fuel Cell (PEFCs) application. J. Power Sources 2007, 171, 540-545. [CrossRef]

(C) 2017 by the authors. Licensee MDPI, Basel, Switzerland. This article is an open access article distributed under the terms and conditions of the Creative Commons Attribution (CC BY) license (http:/ / creativecommons.org/licenses/by/4.0/). 